\title{
チオシアン酸アンモニウム水溶液中における $\mathrm{PC}$ 鋼棒の水素吸蔵挙動*
}

\author{
土信田知樹**，高井健一***，市場幹之 \\ ** 上智大学大学院 理工学研究科 \\ *** 上智大学 理工学部 機能創造理工学科 \\ $†$ 東京電力株式会社 技術開発研究所
}

\author{
Hydrogen Absorption Behavior of Steel Bar for Prestressed Concrete in \\ a Solution of Ammonium Thiocyanate \\ Tomoki Doshida**, Kenichi Takai*** and Mikiyuki Ichiba \\ ** Graduate School of Science and Technology, Sophia University \\ *** Department of Engineering and Applied Science, Faculty of Science and Technology, Sophia University \\ † \& D Center, Tokyo Electric Power Company
}

\begin{abstract}
A solution of ammonium thiocyanate is used in the FIP (Fédération International de la Précontrainte) test as a hydrogen charging method. Though this method is comparatively simple, fracture time in the FIP test and hydrogen content often differ among various testing institutes. However, the detailed hydrogen absorption behavior in the solution is still not clear. In this context, the effects of existing states of hydrogen, oxide film on the specimen surface, specific solution volume to specimen surface area, immersion time and solution temperature on the hydrogen absorption behavior of a steel bar for reinforcing prestressed concrete were investigated by immersing it in the solution. The amount of absorbed hydrogen increased with immersion time, reached its maximum, and then decreased with increasing immersion time. A main factor of the decrease in the amount of absorbed hydrogen was corrosion products, including $\mathrm{Fe}, \mathrm{O}$ and $\mathrm{S}$, formed on the specimen surface, since the amount of absorbed hydrogen increased again as a result of merely polishing the surface. This indicates that corrosion products formed on immersing specimens in a solution of ammonium thiocyanate strongly affect hydrogen absorption behavior. Whereas, variation of the solution, such as increase in $\mathrm{pH}$, during immersion also affects slightly hydrogen absorption behavior.
\end{abstract}

Key words : hydrogen, steel bar for prestressed concrete, ammonium thiocyanate, corrosion, Fédération Internationale de la Précontrainte, existing state of hydrogen, thermal desorption analysis, corrosion product

1. 緒

\section{言}

PC (Prestressed Concrete) 鋼材の水素脆化特性を評価 する一つの方法として, 国際プレストレストコンクリート連 盟 (FIP : Fédération Internationale de la Précontrainte) で 国際的に規格化された試験（以下，FIP 試験と略す）があ る $^{1), 2)}$ 。この FIP 試験とは, チオシアン酸アンモニウム 水溶液中で PC 鋼材に水素を吸蔵させながら一定荷重を 負荷し, 破断までの時間を測定する試験である. 試験環 境がチオシアン酸アンモニウム水溶液であるため, コン クリート構造物の環境を模擬しておらず，寿命を見積も ることはできないが, 水素脆化が PC 鋼材の遅れ破壊の 寿命を決めている主因子であるため, 鋼材間の相対的評 価がある程度可能3)-8) であり, かつ容易な試験のため品 質管理などに活用されている。 その他，チオシアン酸ア ンモニウム水溶液浸漬は各種水素脆化の実験で必須とな る水素添加方法の一つとして用いられている象17).

しかし，FIP 試験方法は比較的簡便であるにも関わら ず，試験機関によって破断時間にばらつきが生じること

* 材料と環境 2010 (東京, 2010) にて発表

**, *** T102-8554 東京都千代田区紀尾井町 7-1 (7-1, Kioi-cho, Chiyoda-ku, Tokyo, 102-8554 Japan)

干230-8510 横浜市鶴見区江ヶ崎町 4-1 (4-1, Egasaki-cho, Tsurumi-ku, Yokohama, 230-8510 Japan)
があり，その原因究明と再現性の向上が望まれている。 基本的には，応力と水素によって PC 鋼材を破壊させる 試験であり，応力に関しては定荷重試験機にて一定の重 りをつるすことで負荷するため, 応力の変動は考えにく い。一方，水素に関しては，チオシアン酸アンモニウム 水溶液中における浸漬条件によって, PC 鋼材の腐食挙 動が変化し, 水素吸蔵挙動も変化して, その結果, 破断 時間が変化する可能性が考えられる18)。しかし，FIP 試 験を規定した際のテクニカルレポート1)では, チオシア ン酸アンモニウム水溶液の浸漬条件と破断時間の関係に ついて検討されたが, 腐食挙動, 水素吸蔵挙動について の詳細な検討はなされていない。 そこで最近, チオシア ン酸アンモニウム水溶液中での PC 鋼材の腐食挙動につ いて詳細な検討がなされてきている ${ }^{19)}$. この腐食挙動に 対応する水素吸蔵挙動を明らかにできれば，チオシアン 酸アンモニウム水溶液浸漬から破断に至るまでの現象を 把握することが可能となる。これらの知見を基に，水素 量を精度よく制御できれば，FIP 試験結果の再現性向上， さらには水素脆化研究の基盤技術として重要な再現性の よい水素添加方法確立への展開が期待される.

以上の観点から本研究では, チオシアン酸アンモニウ 么水溶液における PC 鋼棒20) の水素吸蔵挙動について検 討した。具体的には, 他の水素添加方法との水素存在状 態の比較, $\mathrm{PC}$ 鋼棒の水素吸蔵挙動に及ぼす表面酸化皮 膜, 比液量, 浸漬時間, 溶液温度の影響について検討し た。さらには, チオシアン酸アンモニウム水溶液浸漬に 
よる水素添加法の特徵である浸漬時間とともに水素量が 変化する要因についても考察した。

\section{2. 実 験 方 法}

\section{1 供 試 材}

供試材にはJIS G 3137 D 種 1 号に相当する直径 7.1 $\mathrm{mm}$ の $\mathrm{PC}$ 鋼棒を用いた。金属組織は高周波焼入れ焼戻

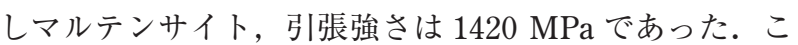
の供試材を長さ $30 \mathrm{~mm}$ に切断し, 試験片とした.

\section{2 水素存在状態に及ぼす水素添加方法の影響}

FIP で規定されたチオシアン酸アンモニウム水溶液を 用いた浸漬法 ${ }^{1)}$ ，および比較のため，一般に使用されて いる水素添加方法である希釈硫酸水溶液を用いた定電流 陰極電解法 ${ }^{21)}$ の 2 種類を用い, 水素添加方法による鋼中 の水素存在状態の差異について検討した.

水素添加前に, 試験片表面をエメリー紙で機械研磨し, 酸化皮膜の除去（脱スケール）および表面状態を均一に した. 水素添加は, $50^{\circ} \mathrm{C}, 20 \mathrm{mass} \%$ チオシアン酸アン モニウム水溶液での浸漬法 (FIP 規定の条件), および $\mathrm{pH} 2.0$, 電流密度 $30 \mathrm{~A} / \mathrm{m}^{2}, 50^{\circ} \mathrm{C}$ の希釈硫酸水溶液を用 いた定電流陰極電解法とした. 水素添加 $48 \mathrm{~h}$ 後, 試験片 を溶液から取り出し, 腐食生成物を拭き取ることで機械 的に除去し，アセトン洗浄を施して，ただちに水素分析 を行った。水素分析には昇温脱離分析法 (Thermal Desorption Analysis：以下，TDA）を用い，Ar 中に50 vol ppm 水素を含んだ標準ガスでキャリブレーションしたガ スクロマトグラフを検出系とし, 室温から $300{ }^{\circ} \mathrm{C}$ ま゙ $100^{\circ} \mathrm{C} \mathrm{h}^{-1}$ で昇温し, $5 \mathrm{~min}$ に 1 回の間隔で放出される水 素をサンプリングした。

\section{3 水素量に及ぼす表面酸化皮膜の影響}

$\mathrm{PC}$ 鋼棒の表面は製造段階で形成された酸化皮膜（スケ ール）で覆われており，この酸化皮膜が水素量に及ぼす影 響について検討した。一方は酸化皮膜をそのまま残した 試験片，他方はエメリー紙で金属光沢が得られるまで研
磨し脱スケールした試験片を準備した。 $50^{\circ} \mathrm{C} ， 20 \mathrm{mass} \%$ チオシアン酸アンモニウム水溶液 (比液量 $20 \mathrm{ml} / \mathrm{cm}^{2}$ ) へ 0 200 h 浸漬し, 試験片を溶液から取り出し, 腐食生成 物を拭き取ることで機械的に除去し，アセトン洗浄を施 して，ただちにTDAを用いて水素量を測定した。なお， 最大浸漬時間を $200 \mathrm{~h}$ とした理由は, FIP 試験で規定さ れている最大試験時間と合わせたためである.

\section{4 水素量, $\mathrm{pH}$ に及ぼす浸漬時間, 比液量の影響}

$\mathrm{PC}$ 鋼棒の水素量に及ぼす浸漬時間および比液量の影 響について検討した。浸漬前に, 試験片表面をエメリー 紙で機械研磨し, 脱スケールおよび表面状態を均一にし た. 比液量を $5,10,20,40 \mathrm{ml} / \mathrm{cm}^{2}$ と変化させた $50^{\circ} \mathrm{C}, 20$ mass\%チオシアン酸アンモニウム水溶液へ 0 ～200 h 浸 漬し, 試験片を溶液から取り出し, 腐食生成物を拭き取 ることで機械的に除去し，アセトン洗浄を施して，ただ ちにTDAを用いて水素量を測定した。なお，比液量は （溶液量/試験片の表面積）とした.

\section{5 水素量に及ぼす溶液温度の影響}

FIP 試験で規定された溶液温度は $50^{\circ} \mathrm{C}$ である゙， $30^{\circ} \mathrm{C}$ および $70^{\circ} \mathrm{C}$ と変化させることで, $\mathrm{PC}$ 鋼棒の水素量に及 ぼす溶液温度の影響について検討した。浸漬前に, 試験 片をエメリー紙で機械研磨し，脱スケールおよび表面状 態を均一にした。 $30,50,70^{\circ} \mathrm{C}$ の $20 \mathrm{mass} \%$ チオシアン酸 アンモニウム水溶液 (比液量 $20 \mathrm{ml} / \mathrm{cm}^{2}$ ) 中へ $0 \sim 200 \mathrm{~h}$ 浸漬し, 試験片を溶液から取り出し, 腐食生成物を拭き 取ることで機械的に除去し，アセトン洗浄を施して，た だちに TDAを用いて水素量を測定した。

\section{3. 実 験 結 果}

\section{1 水素存在状態に及ぼす水素添加方法の違いの影響}

Fig. 1 は，PC 鋼棒（脱スケール後）に2 種類の方法で 水素添加後, TDAにより得られた水素放出温度プロファ イルを示したものである. Fig. 1 (a)に $50^{\circ} \mathrm{C}$ ， 20 mass\% チオシアン酸アンモニウム水溶液へ $48 \mathrm{~h}$ 浸漬した結果,
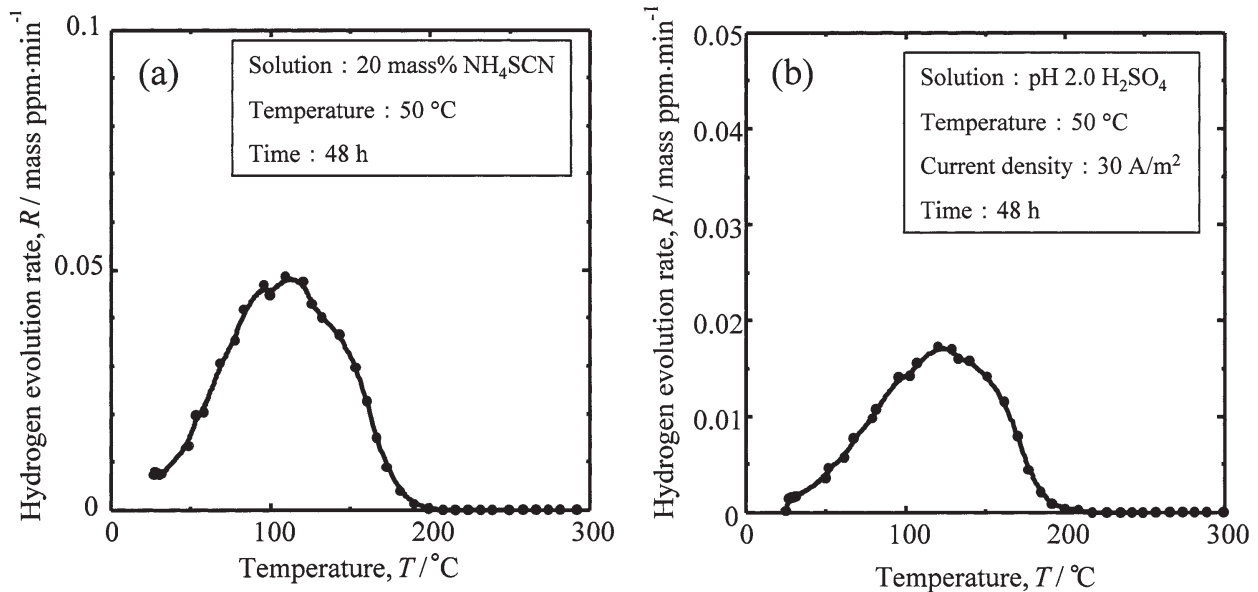

Fig. 1 TDA profiles of steel bar for prestressed concrete (descaled) after hydrogen charging for $48 \mathrm{~h}$ at $50^{\circ} \mathrm{C}$; (a) immersion in a 20 mass \% $\mathrm{NH}_{4} \mathrm{SCN}$ solution with a specific solution volume to specimen surface area of $20 \mathrm{ml} / \mathrm{cm}^{2}$ and (b) cathodic electrolysis hydrogen charging at a current density of $30 \mathrm{~A} / \mathrm{m}^{2}$ in an aqueous solution of $\mathrm{H}_{2} \mathrm{SO}_{4}$ at $\mathrm{pH}$ 2.0. The specific solution volume to specimen surface area is defined as the ratio of solution volume to specimen surface area. 
および Fig. 1(b)に $50^{\circ} \mathrm{C}, \mathrm{pH} 2.0$ 希 硫酸水溶液中, 電流密度 $30 \mathrm{~A} / \mathrm{m}^{2}$ で $48 \mathrm{~h}$ 除極電解法で水素チャージ した結果を示す. Fig. 1(a)と (b)の 水素放出温度プロファイルを比較 すると, PC 鋼棒中に吸蔵された 水素はどちらも室温から放出を開 始し約 $200{ }^{\circ} \mathrm{C}$ で放出を終了する. また，水素放出ピーク温度も約 $120^{\circ} \mathrm{C}$ と一致する。この存在状態 の水素は室温に保持すると徐々に 鋼材中から拡散放出するため, ど ちらも拡散性水素である22, 23).

以上より，溶液中で鋼材を腐食 させアノード反応に伴うカソード 反応により水素を吸蔵させるチオ シアン酸アンモニウム水溶液浸漬 法, および鋼材をカソード, 白金 をアノードとすることで, 鋼材を

腐食させずに水素を吸蔵させる定電流㓌極電解法の 2 つ の方法による鋼材表面での水素の侵入機構は異なるが, これら 2 つ水素放出温度プロファイルはほぼ相似形で あることから, 鋼材中へ水素が侵入すれば水素存在状態 はほぼ同一であることがわかる。

\section{2 水素量に及ぼす表面酸化皮膜の影響}

Fig. 2 は, Fig. 1 (a) と同様の $50^{\circ} \mathrm{C}, 20$ mass\%チオシア ン酸アンモニウム水溶液へ $0 \sim 200 \mathrm{~h}$ 浸漬し, PC 鋼棒中 の水素量に及ぼす表面酸化皮膜の影響を示したものであ る. $24 \mathrm{~h}$ 浸漬までは脱スケールした試験片の水素量が若 干多いが，その後大きな差はない。

以上より，チオシアン酸アンモニウム水溶液への浸漬 初期段階では, PC 鋼棒表面に元々形成されている酸化 皮膜による水素吸蔵抑制効果が若干認められるが, 浸漬 $24 \mathrm{~h}$ 以降では酸化皮膜による水素吸蔵の抑制効果は認め られない。

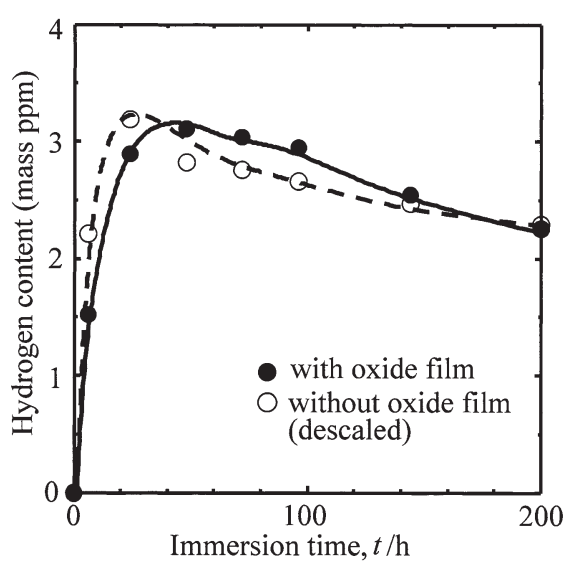

Fig. 2 Effects of oxide film on steel bar for prestressed concrete on hydrogen content after immersion for $0-200 \mathrm{~h}$ in a 20 mass $\% \mathrm{NH}_{4} \mathrm{SCN}$ solution at a specific solution volume to specimen surface area of $20 \mathrm{ml} / \mathrm{cm}^{2}$ at $50^{\circ} \mathrm{C}$; with oxide film $(\mathbf{O})$ and without oxide film $(\bigcirc)$.

\section{3 水素量, $\mathrm{pH}$ に及ぼす浸漬時間, 比液量の影響}

Fig. $3(\mathrm{a})$ は, 比液量を $5,10,20,40 \mathrm{ml} / \mathrm{cm}^{2}$ と変化させ た $50^{\circ} \mathrm{C}, 20 \mathrm{mass} \%$ チオシアン酸アンモニウム水溶液へ $\mathrm{PC}$ 鋼棒 (脱スケール後) を 0 200 h 浸漬し, TDAを用 いて測定した水素量に及ぼす浸漬時間および比液量の影 響を示したものである。Fig. 3(b) は，溶液の pH に及ぼ す浸漬時間および比液量の影響を示したものである. Fig. 3 (a)より，浸漬時間の増加とともに水素量は増加し， 24 48 h でピークに達し, その後緩やかに減少する. 次 に, 比液量に関しては, 比液量 $5 \mathrm{ml} / \mathrm{cm}^{2}$ の場合のみ最 大到達水素量が約 2.7 mass ppm と低く, 浸漬時間 $200 \mathrm{~h}$ までの水素量も他の比液量に比べ低い。一方, 比液量 $10,20,40 \mathrm{ml} / \mathrm{cm}^{2}$ においては, 最大到達水素量が約 3.1 mass ppm であり, 顕著な水素量の差は認められない. また, Fig. 3(b)で示した各時間浸漬後の溶液の $\mathrm{pH}$ 変化 に関しては，実験開始前の溶液は $\mathrm{pH} 4.4$ であり，PC 鋼 棒を $24 \mathrm{~h}$ 浸漬後には $\mathrm{pH} 6$ 近くまで急激に増加し, その 後は $\mathrm{pH} 6$ 前後で安定する.

以上のことから, チオシアン酸アンモニウム水溶液中 での浸漬時間とともに水素量は増加し, 最大水素量に到 達後に減少する傾向はいずれの比液量でも共通してい る. また, 比液量を $5 \mathrm{ml} / \mathrm{cm}^{2}$ まで少なくすると, 最大 到達水素量およびその後の水素量も少ない. 溶液の $\mathrm{pH}$ に関しては, 浸漬時間とともに増加し, その後 $\mathrm{pH} 6$ 前 後で一定となる。この $\mathrm{pH}$ が一定となった後も水素量が 減少し続ける結果は, 水素量減少が水溶液の $\mathrm{pH}$ 以外の 因子の影響を大きく受けていることを示唆している.

\section{4 水素量に及ぼす溶液温度の影響}

Fig. 4 に PC 鋼棒（脱スケール後）をチオシアン酸アン モニウム水溶液へ各時間浸漬し, TDAにより得られた水 素放出温度プロファイルを示す. Fig. 4 (a), (b), (c) は, 比 液量を $20 \mathrm{ml} / \mathrm{cm}^{2}$ と一定にして, 溶液温度をそれぞれ $30,50,70^{\circ} \mathrm{C}$ の 20 mass\%チオシアン酸アンモニウム水溶 液へ 0〜200 h 浸漬した結果である．溶液温度によらず， 最大水素量に到達するまでは, PC 鋼棒中の水素は室温 から放出を開始し約 $200^{\circ} \mathrm{C}$ で放出を終了する単一のピー 

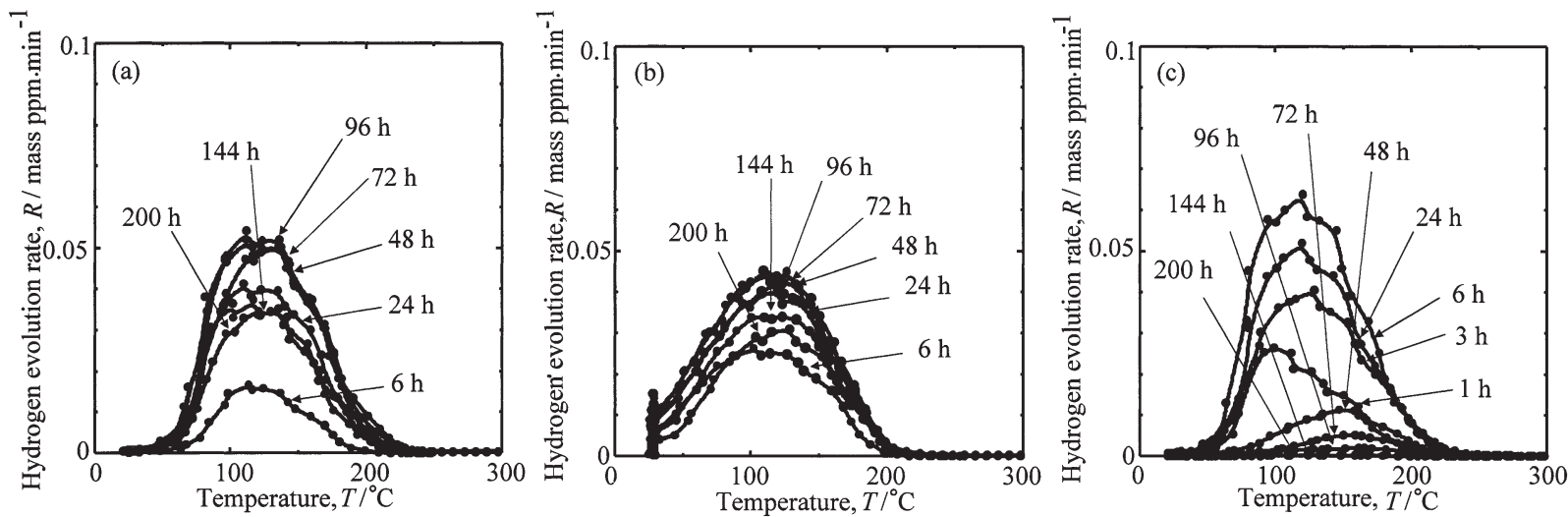

Fig. 4 TDA profiles of steel bar for prestressed concrete (descaled) after immersion for 0-200 $\mathrm{h}$ in a 20 mass $\% \mathrm{NH}_{4} \mathrm{SCN}$ solution at a specific solution volume to specimen surface area of $20 \mathrm{ml} / \mathrm{cm}^{2}$ at (a) $30^{\circ} \mathrm{C}$, (b) $50^{\circ} \mathrm{C}$ and (c) $70^{\circ} \mathrm{C}$, respectively.

クであることから，この溶液温度範囲で水素添加しても 鋼中の水素存在状態に顕著な変化はないことがわかる. これら水素放出温度プロファイルの面積から水素量を算 出し, 水素量と溶液温度, 浸漬時間の関係に整理し直し たものを Fig. 5 に示す. いずれの溶液温度においても水 素量は浸漬時間とともに増加し, 最大水素量到達後, 減 少する傾向は共通する。しかし，溶液温度によって
(A) 水素吸蔵速度
(B) 最大到達水素量
(C) 水素減少速度

が大きく異なる。

(A) の水素吸蔵速度に関しては, 溶液温度 $70^{\circ} \mathrm{C}$ の場合 に浸漬時間に対する水素量の増加割合が最も大きく, 次 いで $50^{\circ} \mathrm{C}, 30^{\circ} \mathrm{C}$ の順である。すなわち，溶液温度が高い ほど水素吸蔵速度は大きい。（B)の最大到達水素量に関 しては, $70^{\circ} \mathrm{C}$ の場合が 3.6 mass ppm と最も多く, 次いで $50^{\circ} \mathrm{C}$ の 3.3 mass ppm, $30^{\circ} \mathrm{C}$ の 3.1 mass ppmの順である. すなわち，溶液温度が高いほど最大到達水素量も多い。 (C)の水素減少速度に関しては, $70^{\circ} \mathrm{C}$ の場合に短時間に 著しく水素量が減少し，100 h 後には浸漬しているにも 関わらずほぼ 0 mass ppm となる。 また， $50^{\circ} \mathrm{C}$ と $30^{\circ} \mathrm{C} に$

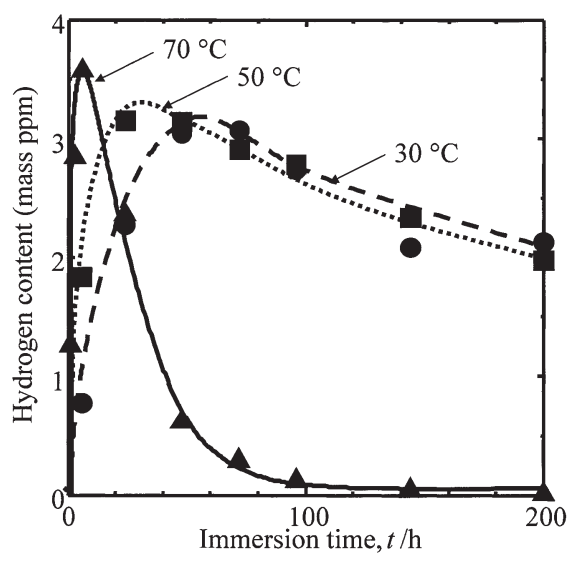

Fig. 5 Effects of immersion time and solution temperature at $30^{\circ} \mathrm{C}(-), 50^{\circ} \mathrm{C}(\boldsymbol{\square})$ and $70^{\circ} \mathrm{C}(\boldsymbol{\Delta})$ on hydrogen content of steel bar for prestressed concrete (descaled) in a 20 mass $\% \mathrm{NH}_{4} \mathrm{SCN}$ solution at a specific solution volume to specimen surface area of $20 \mathrm{ml} / \mathrm{cm}^{2}$.
おいてはほぼ同じ速度で徐々に減少する.

Fig. 5 の実験において, チオシアン酸アンモニウム水 溶液から PC 鋼棒を各時間で取り出す直前の溶液の概観 写真を Fig. 6 に示す. 浸漬開始時 $0 \mathrm{~h}$ のチオシアン酸ア ンモニウム水溶液は無色透明であるが，溶液温度が高い ほど，短時間で水溶液の色が茶褐色へ変化する。また， Fig. 5 の実験において各時間で取り出した直後の PC 鋼 棒の概観写真を Fig. 7 に示す. 浸漬開始前 $0 \mathrm{~h}$ では脱ス ケールしたことにより，PC 鋼棒の表面は金属光沢を帯 びている。一方， $24 \mathrm{~h}$ 浸漬後においては， $30^{\circ} \mathrm{C}$ おび $50^{\circ} \mathrm{C}$ 溶液では，まだ一部分に金属光沢が残っているが, $70^{\circ} \mathrm{C}$ 溶液においては $24 \mathrm{~h}$ 浸漬で既に光沢はなく, 全面に わたって黒色の皮膜に覆われている。 $200 \mathrm{~h}$ 浸漬後にお いては, $30,50,70^{\circ} \mathrm{C}$ のすすれの溶液温度においても, 全 面にわたって黒色の皮膜に覆われている。すなわち， $70^{\circ} \mathrm{C}$ と溶液温度が高いと, 短時間で黒色の腐食生成物が 形成する。

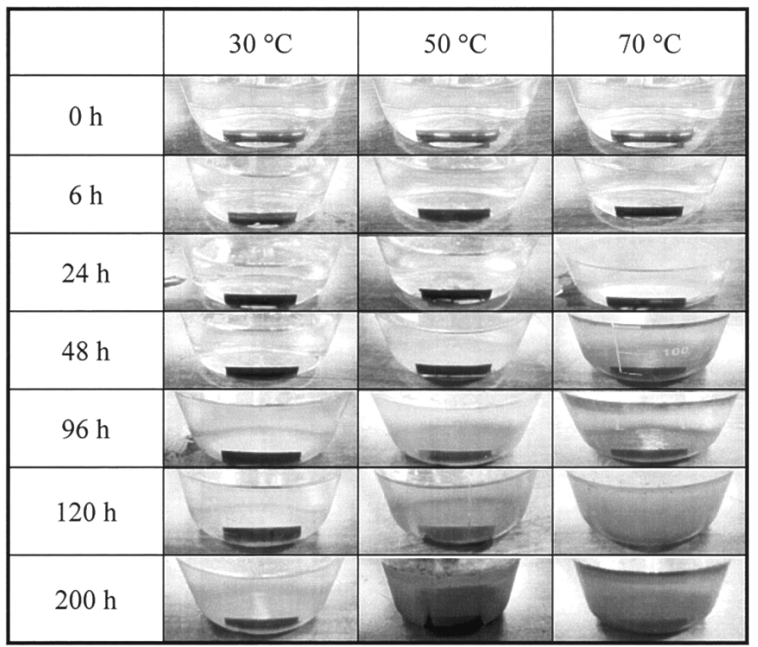

Fig. 6 Photographs of 20 mass $\% \mathrm{NH}_{4} \mathrm{SCN}$ solutions after immersion for $0-200 \mathrm{~h}$ in a 20 mass $\% \mathrm{NH}_{4} \mathrm{SCN}$ solution at a specific solution volume to specimen surface area of 20 $\mathrm{ml} / \mathrm{cm}^{2}$ at $30^{\circ} \mathrm{C}, 50^{\circ} \mathrm{C}$ and $70^{\circ} \mathrm{C}$, respectively. 


\begin{tabular}{|c|c|c|c|}
\hline & $30^{\circ} \mathrm{C}$ & $50^{\circ} \mathrm{C}$ & $70^{\circ} \mathrm{C}$ \\
\hline $0 \mathrm{~h}$ & & & \\
\hline $24 \mathrm{~h}$ & & \\
\hline $200 \mathrm{~h}$ & & \\
\hline
\end{tabular}

Fig. 7 Photographs of the surfaces on the steel bars for prestressed concrete in a 20 mass $\% \mathrm{NH}_{4} \mathrm{SCN}$ solution at a specific solution volume to specimen surface area of $20 \mathrm{ml} / \mathrm{cm}^{2}$ under various immersion times and solution temperatures.

\section{4. 考察}

\section{1 チオシアン酸アンモニウム水溶液浸漬中における 水素量減少の要因}

チオシアン酸アンモニウム水溶液に浸漬した際の水素 吸蔵挙動の特徵の一つとして, 最大水素量に到達後, 水 素量の減少傾向が Fig. 2, 3, 5 で共通して認められた. 特 にその減少傾向が顕著に表れたのが, Fig. 5 の $70^{\circ} \mathrm{C}$ 溶液 浸漬においてであった。一方, 陰極電解水素チャージに おいては，水素チャージ時間とともに水素量は増加し， 試験片表面から中心まで水素濃度が平衡に達すると，一 般に水素量は一定となる ${ }^{21)}$, 24) そこで, 水素量減少のい くつかの要因として, 浸漬時間の増加とともに, (1)Fig. 3(b) で示した pH の増加, 2Fig. 6 で示した溶液の茶褐 色化から $\mathrm{Fe}^{2+}$ 溶出に伴う溶存酸素の減少, (3)次節で示す Fig. 13 のように腐食生成物中に S 濃化層を形成すること で溶液中の $\mathrm{SCN}^{-}$が分解・減少し触媒毒の作用の低下, などのチオシアン酸アンモニウム水溶液の経時変化によ る水素吸蔵能の低下が考えられる。一方, 溶液以外の要 因として, 浸漬時間の増加とともに Fig. 7 で示した試験 片表面の腐食生成物形成，すなわち腐食生成物がバリア となることで水素吸蔵能の低下が考えられる.

そこで, 以下で示す (i)の溶液側か (ii)の試験片表面側 かどちらが主要因であるかについて考察する。

（i） 腐食に伴う $\mathrm{pH}$ の上昇などのチオシアン酸アンモ ニウム水溶液の経時変化

(ii) 腐食生成物形成

Fig. 8 に浸漬時間の増加に伴い水素量が減 少した要因を考察するための実験手順を示 す. 各試験条件に(1)〜 (10)の番号を付与し

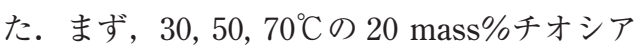
ン酸アンモニウム水溶液 (比液量 $20 \mathrm{ml} / \mathrm{cm}^{2}$ ) 中で $200 \mathrm{~h}$ 予備浸漬し, 水素量が減少し続け ている段階の溶液と試験片をそれぞれ準備し た。その後, 新しい溶液への交換の有無, お よび $200 \mathrm{~h}$ 予備浸漬で形成した腐食生成物の 除去の有無を組み合わせて, 再度, 30, 50, $70^{\circ} \mathrm{C}$ の 20 mass\%チオシアン酸アンモニウム 水溶液 (比液量 $20 \mathrm{ml} / \mathrm{cm}^{2}$ ) 中へ $24 \mathrm{~h}$ および $48 \mathrm{~h}$ 浸漬し, TDA を用いて水素量を測定し た.（1)，(2) は基準となる $200 \mathrm{~h}$ 予備浸漬後の 水素量を測定したものである。（3），(4) は 200 $\mathrm{h}$ 予備浸漬で形成した腐食生成物を残したま ま, 溶液交換のみを行い $24,48 \mathrm{~h}$ 再浸漬後の
水素量を測定したものである。（5），(6) は溶液 交換し, かつ表面研磨を行い $200 \mathrm{~h}$ 予備浸漬で 形成した腐食生成物を除去して $24,48 \mathrm{~h}$ 再浸漬 後の水素量を測定したものである。（7)，(8)は 溶液交換および表面研磨を行わずそのまま継続 して 24, $48 \mathrm{~h}$ 再浸漬後の水素量を測定したもの である。（9），(10）は溶液交換せずに表面研磨の みを行い $24,48 \mathrm{~h}$ 再浸漬後の水素量を測定した ものである。

Table 1 に(1)〜(10)の実験条件と得られた水 素量を示す。また，この水素量に及ぼす溶液交 換と表面研磨の影響を浸漬時間で整理したものを Fig. 9 〜11 に示す.

Fig. 9 (a) は，溶液温度 $30^{\circ} \mathrm{C}$ の 20 mass\%チオシアン酸 アンモニウム水溶液 (比液量 $20 \mathrm{ml} / \mathrm{cm}^{2}$ ) 中で $200 \mathrm{~h}$ 予備 浸漬過程での水素量, およびその後に溶液交換の有無, 表面研磨の有無を組み合わせた 4 条件で，それぞれ 24 , $48 \mathrm{~h}$ 再浸漬を継続した際の水素量を示したものである. また, Fig. 9 (b) に，溶液交換と表面研磨を組み合わせた ことによる水素量変化の拡大図 (Fig. 9 (a)の点線部分の 拡大図) を示す。なお, 図中の $(1) \sim(10)$ の各プロットは Fig. 8 および Table 1 の実験条件 (1)〜 (10) に対応してい る. $200 \mathrm{~h}$ 予備浸漬終了時の水素量 (1), (2) と比較して, 浸漬後に形成した黒色の腐食生成物を除去し再浸漬した

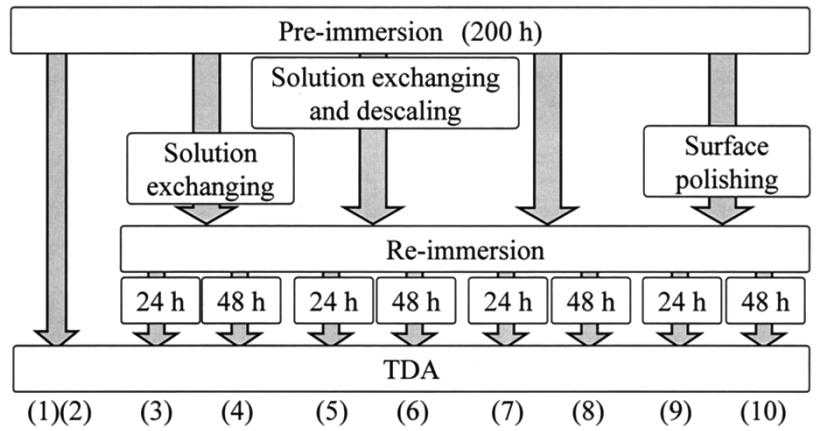

Fig. 8 Procedures for clarify the factor of the decrease in hydrogen content with increase in immersion time.

Table 1 Experimental conditions and hydrogen contents of steel bar for prestressed concrete (descaled) re-immersed for 24 or $48 \mathrm{~h}$ with the combination of solution exchanging and surface polishing after pre-immersion. The pre-immersion was conducted for $200 \mathrm{~h}$ in a 20 mass $\%$ $\mathrm{NH}_{4} \mathrm{SCN}$ solution with a specific solution volume to specimen surface area of $20 \mathrm{ml} / \mathrm{cm}^{2}$ at $30^{\circ} \mathrm{C}, 50^{\circ} \mathrm{C}$ and $70^{\circ} \mathrm{C}$, respectively.

\begin{tabular}{|c|c|c|c|c|c|c|}
\hline \multirow{2}{*}{$\begin{array}{c}\text { Condition } \\
\text { No. }\end{array}$} & \multirow{2}{*}{$\begin{array}{l}\text { Solution } \\
\text { exchanging }\end{array}$} & \multirow{2}{*}{$\begin{array}{c}\text { Surface } \\
\text { polishing }\end{array}$} & \multirow{2}{*}{$\begin{array}{c}\text { Re- } \\
\text { immersion }\end{array}$} & \multicolumn{3}{|c|}{ Hydrogen contents (mass ppm) } \\
\hline & & & & $30^{\circ} \mathrm{C}$ & $50^{\circ} \mathrm{C}$ & $70^{\circ} \mathrm{C}$ \\
\hline (1) & - & - & - & 2.13 & 2.14 & 0.01 \\
\hline (2) & - & - & - & 2.08 & 2.08 & 0.02 \\
\hline (3) & Yes & No & $24 \mathrm{~h}$ & 2.07 & 2.07 & 0.08 \\
\hline (4) & Yes & No & $48 \mathrm{~h}$ & 2.02 & 1.83 & 0.02 \\
\hline (5) & Yes & Yes & $24 \mathrm{~h}$ & 2.94 & 2.93 & 2.49 \\
\hline (6) & Yes & Yes & $48 \mathrm{~h}$ & 2.88 & 2.49 & 0.52 \\
\hline (7) & No & No & $24 \mathrm{~h}$ & 1.97 & 1.98 & 0.04 \\
\hline$(8)$ & No & No & $48 \mathrm{~h}$ & 1.86 & 1.81 & 0.02 \\
\hline (9) & No & Yes & $24 \mathrm{~h}$ & 2.80 & 2.56 & 2.45 \\
\hline (10) & No & Yes & $48 \mathrm{~h}$ & 2.77 & 2.46 & 0.69 \\
\hline
\end{tabular}



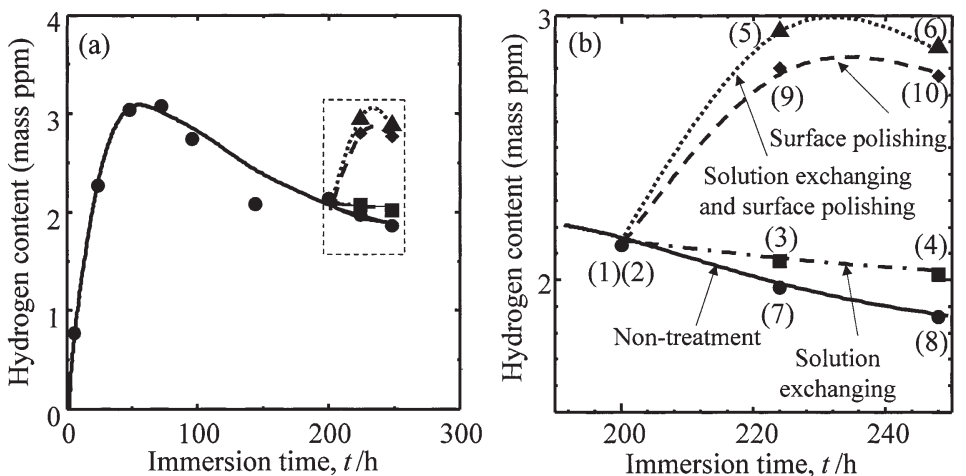

Fig. 9 Effects of solution exchanging and surface polishing on hydrogen content of steel bar for prestressed concrete after immersion in a 20 mass $\% \mathrm{NH}_{4} \mathrm{SCN}$ solution at $30^{\circ} \mathrm{C}$; (a) overall figure and (b) magnified figure. The $(\boldsymbol{\square}),(\boldsymbol{\Delta}),(\boldsymbol{)})$ and $(\bullet)$ symbols denote the effects of only solution exchanging, both solution exchanging and surface polishing, non-treatment and only surface polishing, respectively.
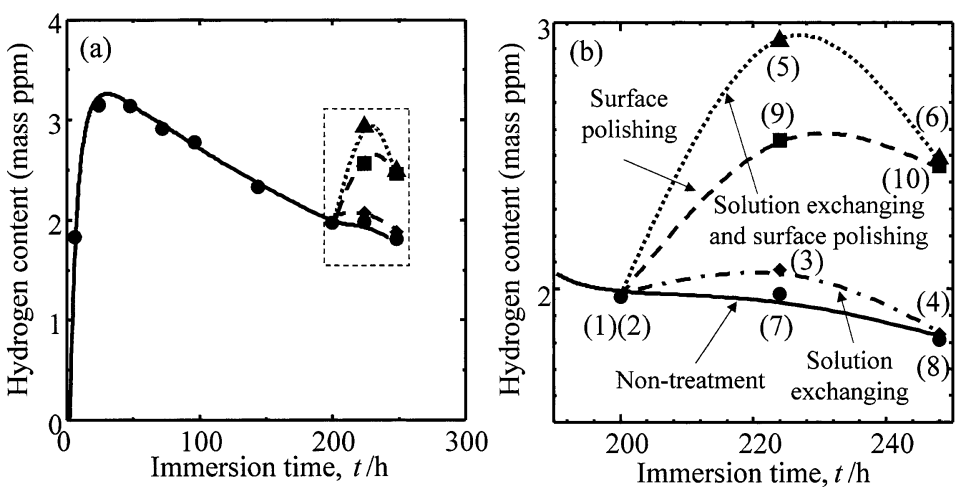

Fig. 10 Effects of solution exchanging and surface polishing on hydrogen content of steel bar for prestressed concrete after immersion in a 20 mass $\% \mathrm{NH}_{4} \mathrm{SCN}$ solution at $50^{\circ} \mathrm{C}$; (a) overall figure and (b) magnified figure. The $(\boldsymbol{\square}),(\boldsymbol{\Delta}),(\boldsymbol{O})$ and $(\boldsymbol{)})$ symbols denote the effects of only solution exchanging, both solution exchanging and surface polishing, non-treatment and only surface polishing, respectively.
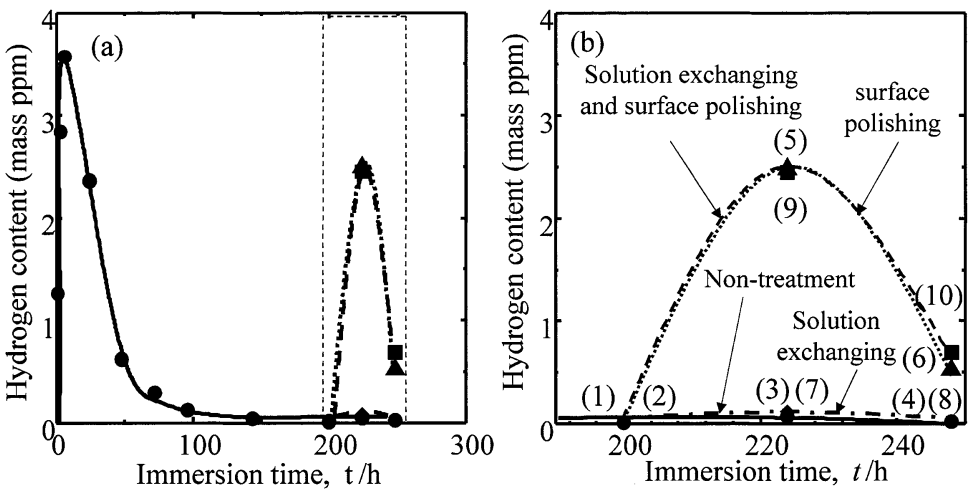

Fig. 11 Effects of solution exchanging and surface polishing on hydrogen content of steel bar for prestressed concrete after immersion in a 20 mass $\% \mathrm{NH}_{4} \mathrm{SCN}$ solution at $70^{\circ} \mathrm{C}$; (a) overall figure and (b) magnified figure. The $(\boldsymbol{\square}),(\boldsymbol{\Delta}),(\boldsymbol{O})$ and $(\checkmark)$ symbols denote the effects of only solution exchanging, both solution exchanging and surface polishing, non-treatment and only surface polishing, respectively.
浸漬で試験片表面に形成した黒色の腐食生 成物を除去することで，再度水素量が大き く増加し始めることから，浸漬時間ととも に水素量が減少する主要因は (ii)の腐食生 成物であることがわかる。しかし，腐食生 成物を除去し，かつ新しい溶液へ交換した 条件 (5)，(6)では，腐食生成物除去のみの 条件 (9), (10)より水素量が若干増加する。 同様に，腐食生成物を除去せずに新しい溶 液へ交換した条件 (3), (4)でも, 溶液交換 および表面研磨を行わず $24,48 \mathrm{~h}$ 再浸漬し た（7），(8)より水素量が若干増加する。 こ れらの結果から, 浸漬時間とともに水素量 が減少する要因として, （i）の腐食に伴う $\mathrm{pH}$ の上昇などのチオシアン酸アンモニウ 么水溶液の経時変化もわずかであるが水素 量に影響を及ぼすことがわかる.

Fig. 10 に溶液温度 $50^{\circ} \mathrm{C}$, Fig. 11 に溶液 温度 $70^{\circ} \mathrm{C}$ の結果を示す. Fig. 9 の $30^{\circ} \mathrm{C}$ と Fig. 10 の $50^{\circ} \mathrm{C}$ の結果はほぼ同様の傾向を 示す。一方, Fig. 11 の $70^{\circ} \mathrm{C}$ の結果に扔い ては, $200 \mathrm{~h}$ 予備浸漬することで約 0 mass ppm まで減少した水素量が，（9）では表面 研磨するだけで再浸漬 $24 \mathrm{~h}$ 後の水素量が 2.45 mass ppm まで大幅に増加する。ただ し, Fig. 5 で示したように $70^{\circ} \mathrm{C}$ の場合は 6 $\mathrm{h}$ 浸漬で既に最大水素量 3.60 mass ppm と なり, それ以降, 水素量が減少する.よっ て, 再浸漬 $24 \mathrm{~h}$ 後では既に減少過程のた め最大水素量 3.60 mass ppm までには戻ら ない。 また，(3)，(4) は溶液交換しても水 素量は約 0 mass ppm のままである.すな わち, $70^{\circ} \mathrm{C}$ のオシアン酸アンモニウム水 溶液浸漬で表面に形成した黒色の腐食生成 物を除去することで, 水素量が急激に増加 し始めることから, 浸漬時間とともに水素 量が減少する主要因は (ii)の腐食生成物で あることがわかる。一方，新しい溶液へ交 換しても腐食生成物を除去しないと水素量 が増加しない理由は， $70^{\circ} \mathrm{C}$ 浸漬で形成する 腐食生成物は, かなり緻密で厚いことが予 想され，この腐食生成物によって溶液と $\mathrm{PC}$ 鋼棒表面が遮断されて, 腐食反応が進 行しないためと推察される.

以上の結果から, いずれの溶液温度にお いても浸漬時間とともに水素吸蔵が抑制さ れる要因は, 主に試験片表面に形成した腐 食生成物である。ただし，腐食に伴う $\mathrm{pH}$ の上昇などのチオシアン酸アンモニウム水 溶液の経時変化もわずかであるが水素吸蔵 抑制に影響を及ぼす。 


\section{2 チオシアン酸アンモニウム水溶液で形成される 腐食生成物}

前節において, 浸漬後に形成した黒色の腐食生成物が 水素吸蔵挙動に大きく影響を及ぼすことが判明した。そ こで，この腐食生成物の厚さおよび成分を調べるために， $30,50,70^{\circ} \mathrm{C}$ の 20 mass\%チオシアン酸アンモニウム水溶 液 (比液量 $20 \mathrm{ml} / \mathrm{cm}^{2}$ ) 中で $6,48,120 \mathrm{~h}$ 浸漬した試験片 を準備した. Fig. 12 にこれら丸棒試験片を長手方向に切 断し，走査電子顕微鏡 $(\mathrm{SEM})$ を用いて観察した結果を 示す。溶液温度が高いほど，かつ浸漬時間が長いほど, 腐食生成物は厚い。溶液温度 $70^{\circ} \mathrm{C}, 120 \mathrm{~h}$ 浸漬において は，腐食生成物の厚さは約 $20 \mu \mathrm{m}$ に達する．この腐食生 成物が水素吸蔵の抑制に大きな影響を及ぼすと推察され る.

Fig. 13 に $30^{\circ} \mathrm{C}, 50^{\circ} \mathrm{C}, 70^{\circ} \mathrm{C}, 120 \mathrm{~h}$ 浸漬で形成した腐食 生成物の SEM 写真と電子プローブ微小部分析 (EPMA) による元素分析結果を示す。腐食生成物の部分では S の 強度が強く, その他に $\mathrm{Fe}, \mathrm{O}$ も含まれる.これらの結果 は本報告と同成分の鋼材で検討を行った既報19) の皮膜分 析の結果と一致している. FIP テクニカルレポート ${ }^{1)}$ で も溶液や皮膜分析で，硫化物や酸化物の検出が報告され ているが，検出元素が異なることから使用した鋼材成分 などに違いがあったものと考えられる。

以上のことから，試験片表面に形成した黒色の腐食生 成物を分析した結果，溶液温度が高いほど，かつ浸漬時

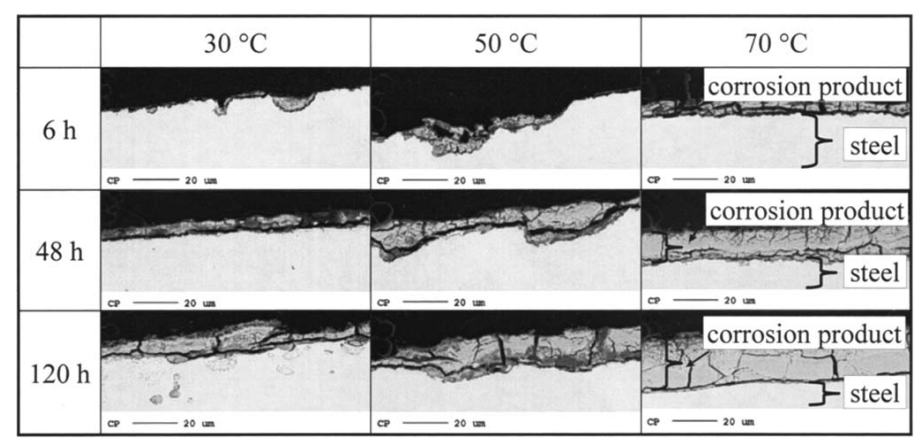

Fig. 12 Scanning electron micrographs of the corrosion product formed by immersion in a 20 mass $\% \mathrm{NH}_{4} \mathrm{SCN}$ solution for 6,48 and $120 \mathrm{~h}$ at $30^{\circ} \mathrm{C}, 50^{\circ} \mathrm{C}$ and $70^{\circ} \mathrm{C}$, respectively.

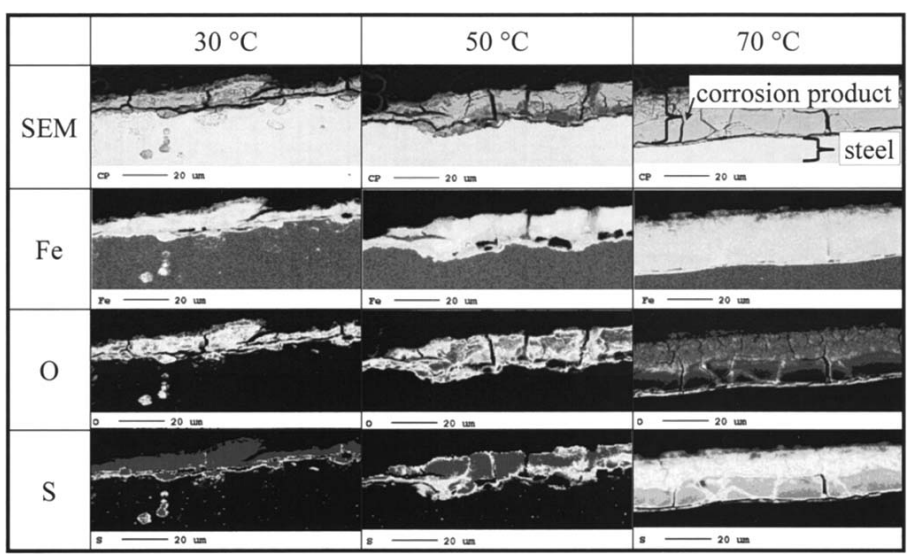

Fig. 13 Scanning electron micrographs and EPMA elemental mappings of $\mathrm{Fe}, \mathrm{O}$ and $\mathrm{S}$ of the corrosion product formed by immersion in a 20 mass $\% \mathrm{NH}_{4} \mathrm{SCN}$ solution for $120 \mathrm{~h}$ at $30^{\circ} \mathrm{C}, 50^{\circ} \mathrm{C}$ and $70^{\circ} \mathrm{C}$.
間が長いほど，腐食生成物は厚く形成され，その成分は 主に Fe, O, S で構成されていることが認められた。

\section{3 チオシアン酸アンモニウム水溶液浸漬における 水素吸蔵挙動}

4.1 節および 4.2 節で得られた知見を基に, Fig. 5 の各 温度における水素吸蔵挙動の差異について考察する。一 般に，固体内を原子が拡散する量は Fickの第 1 法則で決 まる。拡散流速 $J\left(\mathrm{~g} / \mathrm{m}^{2} \cdot \mathrm{s}\right)$ は

$J\left(\mathrm{~g} / \mathrm{m}^{2} \cdot \mathrm{s}\right)=-D(\mathrm{~d} C / \mathrm{d} x)$

となる。ここで， $D$ は見かけの拡散係数 $\left(\mathrm{m}^{2} / \mathrm{s}\right),(\mathrm{d} C /$ $\mathrm{d} x$ ）は濃度勾配である。すなわち，単位時間当たり，単 位面積当たり流れる原子の質量は，見かけの拡散係数 $D$ と濃度勾配の積で決まる。 また, この $D$ は, 以下の式で 表される。

$$
D=D_{0} \exp \left(-E_{D} / \mathrm{R} T\right)
$$

ここで, $D_{0}$ は振動数因子, $E_{D}$ は拡散の活性化エネル ギー $(\mathrm{J} / \mathrm{mol}), \mathrm{R}$ は気体定数, $T$ は絶対温度 $(\mathrm{K})$ である. まず，表面での水素フュガシティ増減に伴い試験片中心 と表面での濃度勾配が変化すると $J$ も変化する。また, 式 (1), (2) より, 温度が変化すると $D$ も変化し, 結果と して $J$ も変化する。すなわち水素吸蔵挙動は, (1) 濃度勾 配，および (2) 見かけの水素拡散係数の積で決まる。以 上の固体内の拡散現象を基に，本研究で得られた 3.4 節 の $(\mathrm{A}) \sim(\mathrm{C})$ の現象について考察する.

(A)の水素吸蔵速度に関しては, 溶液温度が高 いほど水素吸蔵速度は大きかった。この浸漬初期 段階ではまだ腐食生成物で覆われていないため, 水素吸蔵速度は腐食反応に伴う水素発生とその後 の水素拡散に起因する。すなわち, 溶液温度の上 昇とともに，表面水素濃度が高くなるため (1)の 濃度勾配の増加，および式(2)より (2) 見かけの水 素拡散係数の増加, の 2 つの要因により, 水素吸 蔵速度が増加したと推察される。

（B）の最大到達水素量に関しては，溶液温度が 高いほど多かった。これは, 溶液温度が高いほど 自然浸漬電位が卑側にシフトし腐食量が増加する ため ${ }^{25)}$, 最大到達水素量も増加したと考えられ る.

(C) の水素減少速度に関しては， $70^{\circ} \mathrm{C}$ と溶液温 度が高いと最大水素量到達後の水素量減少が著し かった。この第一の要因は, 浸漬時間とともに $\mathrm{Fe}, \mathrm{O}, \mathrm{S}$ を主体とする腐食生成物に覆われること よって腐食速度が低下し19), 表面での水素発生反 応が低下，すなわち試験片中心に比べ表面水素濃 度が著しく低下して，(1)の濃度勾配が増加したた めと考えられる。第二の要因として, 温度上昇に 伴い (2)の見かけの水素拡散係数が増加したこと が考えられる. 以上の 2 つの要因により， $70^{\circ} \mathrm{Cに}$ おいては試験片内部から表面への水素の拡散流速 $J$ が大きくなったため, 水素減少速度が著しかっ たと考えられる。

同様に, Fig. 9〜11 で示したチオシアン酸アン モニウム水溶液浸漬によって形成した腐食生成物 を除去してから再浸漬すると水素量が再び増加し た。この理由は，PC 鋼棒表面が再び活性となり 
腐食速度が増加し, 鋼材表面の水素のフュガシティが増 加したため, (2)の濃度勾配も増加し, 再び水素量が増加 したと推察される。

本研究では, チオシアン酸アンモニウム水溶液浸漬に おける基礎的な水素吸蔵挙動を明らかにした。今後, 得 られた結果を基に, 水素脆化研究の基盤技術として重要 な再現性のよい水素添加方法の確立へ展開する計画であ る.

\section{5. 結}

言

チオシアン酸アンモニウム水溶液浸漬における PC 鋼 棒への水素吸蔵挙動に関する基礎検討を行い，以下の知 見が得られた。

（1）チオシアン酸アンモニウム水溶液浸漬法と定電 流陰極電解法の異なる水素添加方法を用いて PC 鋼棒中 へ水素を吸蔵し水素存在状態を比較した結果, 水素放出 温度プロファイルはほぼ相似形である。すなわち，鋼材 表面での水素侵入機構は異なるが，鋼材中へ水素侵入後 の水素の存在状態はほぼ同一である。

（2）チオシアン酸アンモニウム水溶液への浸漬初期 段階では, PC 鋼棒表面に元々形成されている酸化皮膜 による水素吸蔵抑制効果が若干認められるが，浸漬 $24 \mathrm{~h}$ 以降では水素吸蔵の抑制効果は認められない.

（3）チオシアン酸アンモニウム水溶液中での浸漬時 間とともに水素量は増加し, 最大水素量到達後に減少す る傾向はいずれの比液量でも共通している．また，比液 量を $5 \mathrm{ml} / \mathrm{cm}^{2}$ まで少なくすると, 最大到達水素量およ びその後の水素量も少ない.

（4） PC 鋼棒の水素量に及ぼす温度の影響に関して は， $30,50,70^{\circ} \mathrm{C}$ とチオシアン酸アンモニウム水溶液の温 度が高くなるほど最大水素量に達するまでの浸漬時間が 短く, かつ最大到達水素量が多い. また, いずれの溶液 温度においても共通して最大水素量到達後, 水素量は減 少する. $70^{\circ} \mathrm{C}$ と溶液温度が高いと, 最大水素量到達後の 水素減少速度も大きい.

（5） チオシアン酸アンモニウム水溶液中において, 浸漬時間とともに水素吸蔵が抑制される要因は, 試験片 表面に形成した主として Fe, O, S からなる腐食生成物で ある。この腐食生成物は, 溶液温度が高いほど, かつ浸 漬時間が長いほど，厚く形成する。ただし， pHの上昇 などの溶液の経時変化もわずかであるが水素吸蔵に影響 を及ぼす。

\section{謝辞}

高周波熱錬株式会社より試験材料を提供いただき，深 くお礼申し上げます。また，(社) 腐食防食協会「FIP 試 験分科会」の委員の皆様には, 得られた結果につい有益 なご助言をいただき謝意を表します。

\section{参 考 文 献}

1) Fédération Internationale de la Précontrainte, Report on Prestressing Steel 5, Sep. 1 (1980).

2) T. Maekawa, Proc. 170th Symposium, p.10, JSCE (2010).

3) K. Suehiro, E. Yamashita, S. Mizoguchi, M. Tanimura and T. Shimada, J.Soc. Mater. Sci.Jpn, 32, 222 (2001).

4) M. Nagumo, M. Nakamura and K. Takai, Metall. Mater. Trans. A, 32A, 339 (2001).

5) K. Takai, J. Seki and Y. Homma, Tetsu-to-Hagane, 81, 1025 (1995).

6) K. Takai, J. Seki, E. Sakita and K. Takayama, Tetsu-toHagane, 79, 685 (1993).

7) J. Toribio, Materials \& Design, 18, 81 (1997).

8) M. Elices, J. Ruiz, and J. M. Atienza, Materials and Structures, 37, 305 (2004).

9) Y. Yamaoka, H. Tsubono and M. Kurauchi, PCI Journal, July-August, 146 (1988).

10) M. Nagumo, K. Takai and N. Okuda, J. Alloy. and Compd., 293-295, 310 (1999)

11) K. Takai, G. Yamauchi, M. Nakamura and M. Nagumo, J. Jpn. Inst. Met., 62, 267 (1998).

12) K. Takai, Zairyo-to-Kankyo, 60, 230 (2011).

13) K. Takai, Y. Chiba, K. Noguchi and A. Nozue, Metall. Mater. Trans. A, 33A, 2659 (2002).

14) K. Takai, Zairyo-to-Kankyo, 49, 271 (2000).

15) R. M. Schroeder and I. L. Muller, Corros. Sci., 45, 1969 (2003).

16) Y. Murakami and S. Matsuoka, Eng. Fract. Mech., 77, 1926 (2010).

17) H. Uyama, H. Yamada, H. Hidaka and N. Mitamura, Tribology Online, 6, 123 (2011)

18) Y. Niidome, M. Ichiba, N. Taneichi and K. Takai, Proc. 56th Japan Conf. Materials and Environments, p.393, JSCE (2009).

19) M. Ichiba, Y. Niidome, S. Nakamura and J. Sakai, Zairyo-toKankyo, 59, 332 (2010).

20) T. Okamura and S. Mizoguchi, Proc. 170th Symposium, p.24, JSCE (2010).

21) K. Takai, K. Murakami, N. Yabe, H. Suzuki and Y. Hagihara, J. Jpn Inst. Met., 72, 448 (2008).

22) K. Takai, Trans. Jap. Soc. Mech. Eng. A, 70, 1027 (2004).

23) K. Takai and R. Watanuki, ISIJ Int., 43, 520 (2003).

24) Y. Hagihara, T. Shobu, N. Hisamori, H. Suzuki, K. Takai and K. Hirai, Tetsu-to-Hagane, 97, 143 (2011).

25) K. Abe, M. Ichiba and J. Sakai, Proceedings of JSCE Materials and Environments 2011, p.175, JSCE (2011).

(Manuscript received September 16, 2011; in final form January 11, 2012)

チオシアン酸アンモニウム水溶液浸漬による PC 鋼棒の水素吸蔵挙動を明らかにするため, 水素存在状 態, 酸化皮膜, 比液量, 浸漬時間, 溶液温度の影響について検討した。本溶液の特徵は, 浸漬時間ととも に水素量が増加し, ピークに達した後, 一定で保持されずに減少する。この水素量減少の主要因は, PC 鋼棒表面に形成される腐食生成物である。 また，腐食に伴う $\mathrm{pH}$ の上昇などの溶液の経時変化もわずかで あるが水素量減少に影響を及ぼす。

キーワード＼cjkstart水素，PC 鋼棒，チオシアン酸アンモニウム，腐食，国際プレストレストコンクリート 連盟，水素存在状態，昇温脱離分析，腐食生成物 